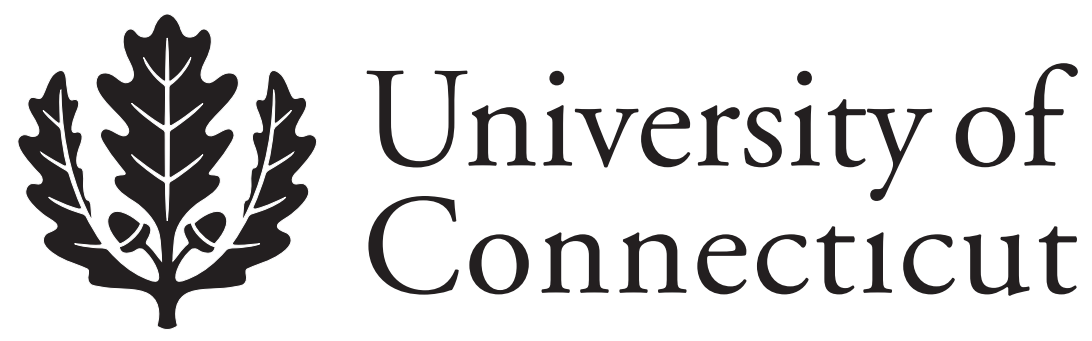

Department of Economics Working Paper Series

\title{
Debtors' Prisons in America: An Economic Analysis
}

Mathhew Baker

Hunter College, City University of New York

Metin Coşgel

University of Connecticut

Thomas J. Miceli

University of Connecticut

Working Paper 2009-33

October 2009

341 Mansfield Road, Unit 1063

Storrs, CT 06269-1063

Phone: (860) 486-3022

Fax: (860) 486-4463

http://www.econ.uconn.edu/

This working paper is indexed on RePEc, http://repec.org/ 


\begin{abstract}
Debtors' prisons have been commonplace throughout history, including in the United States. While imprisonment for debt no doubt elicited some repayment by benefactors of the debtor, we argue that its primary function was to deter default in the first place by giving borrowers an incentive to disclose hidden assets. Because of its cost, however, imprisonment was destined to be replaced by more efficient ways of preventing borrowers from sheltering assets. Empirical analysis of state laws banning imprisonment for debt provides support for this argument. In particular, the results suggest that states in which the publishing industry developed sooner (thus facilitating the flow of information) were more likely to enact early bans on imprisonment for debt.
\end{abstract}

Journal of Economic Literature Classification: D82, E51, G21, K24

Keywords: Debtors' prison, default, imprisonment 


\section{Debtors' Prisons in America: \\ An Economic Analysis}

"Annual income twenty pounds, annual expenditure nineteen nineteen and six, result, happiness. Annual income twenty pounds, annual expenditure twenty pounds ought and six, result misery." -Mr. Micawber's advice to David Copperfield on how to avoid debtors' prison (Dickens, [1850] 2006).

\section{Introduction}

The availability of credit is an important component of a growing economy. A fundamental problem facing any system that relies on credit, however, is how to ensure timely repayment, and also how to deal with those unable to repay. These questions present society with a difficult trade-off because, while an unbending policy toward defaulters is generally necessary to enforce repayment terms, it can result in harsh treatment of those down on their luck. In early English law, the ultimate penalty for defaulters was imprisonment, often at the debtor's own expense, until the debt was paid. Of course, this raises the obvious question of how one could repay debt while in prison, but the underlying presumption was that the threat of imprisonment would induce borrowers to avoid default in the first place. In other words, the prospect of prison would act as a deterrent. Additionally, Mann (2002, p. 79) notes that creditors "hoped that the rigors of imprisonment would induce debtors to disclose concealed wealth or to part with assets that were exempt from attachment or, perhaps, that family members might step into the breach..."1 Still, some debtors were bound to default, and others apparently were willing to sacrifice their freedom in order to protect their assets (Coleman, 1999, p.

\footnotetext{
${ }^{1}$ Also see Holton (2007, p. 43), who notes that the system contained a "cruel logic, since it forced the delinquent debtor to reveal hidden assets..."
} 
9). As a result, debtors' prisons flourished as a costly method for enforcing repayment, both for society and for prisoners.

The fact is that, throughout history, imprisonment for debt was the norm rather than the exception to the rule. Ford (1926) describes the codification of imprisonment for debt in early Roman law, which evidently allowed debtors to be arrested and placed in jail for a prescribed period of time. References to imprisonment for debt can also be found in the bible, where it is suggested that if debts went unpaid by the end of the imprisonment term, the debtor could be killed or sold into slavery. ${ }^{2}$ While the tendency to imprison debtors apparently abated as alternative means of dealing with delinquent debtors developed, it reemerged in full force in the Middle Ages, waned again in the era of feudalism, only to return to prominence in the later Middle Ages, partly through the approval of the Catholic Church.

For a variety of reasons discussed by Ford (1926), debtors' prisons surged in medieval England and spread throughout Europe. In fact, Ford (1926, p. 30) cites the 1834 report of a British parliamentary commission asserting that at the time imprisonment for debt was legal in every country in continental Europe except Portugal. The American colonies imported the practice, and "[b]y the end of the seventeenth century the debtors' prison had become an established colonial institution" (Coleman, 1999, p. 249). The system remained little changed until the beginning of the nineteenth century when most colonies began to enact reforms, driven mainly by humanitarian concerns. And when Massachusetts abolished imprisonment for petty debts in 1811, the

\footnotetext{
${ }^{2}$ See Matthew 18:29-31 (New International Version) on imprisonment for debt. Matthew 18:24-26 describes an episode in which a debtor is to be sold into slavery to repay a debt.
} 
process of eliminating the practice altogether had begun. "Between 1811 and the end of Reconstruction most but not all of the eastern states gradually prohibited the imprisonment of defaulters except in cases of fraud and in damage suits for alimony, child support, and wrongful behavior" (Coleman, 1999, p. 256).

The demise of the debtors' prisons, however, was not driven entirely by compassion for debtors; it also reflected changes in lending practices. As credit became more impersonal, lenders began to require some form of security up front as protection against default. In addition, the legal system facilitated the seizure of secured assets in lieu of payment. Borrowers therefore had a harder time sheltering assets. Debtors' prison thus became an anachronistic and costly way to enforce payment in this world, and undoubtedly it would have disappeared even without legal action (Coleman, 1999, p. 268).

The goal of this paper is threefold. The first is to provide an historical picture of debtors' prisons in the United States as they existed in the early years of the Republic. The second is to develop an economic theory of debtors' prisons, focusing on their role in facilitating efficient lending and repayment of debt, and on the emergence of alternative enforcement measures. Finally, the paper offers some empirical evidence on those factors that led to the demise of debtors' prisons in the United States during the midnineteenth century.

\section{An Overview of Debtors' Prisons in the United States}

While much anecdotal evidence suggests imprisonment for debt was an important

part of life in the United States at the beginning of the $19^{\text {th }}$ century, how prevalent, really, 
was the practice, and how exactly did it function? At least one group, the "Prison Discipline Society," a philanthropic society formed with the aim of improving prison conditions in the United States, kept careful records of debtors in prison. The societies' $5^{\text {th }}$ report, published in part in 1831 , posted the results of a detailed survey of the nature and extent of debtors' prisons across the United States. We present portions of this report in Tables 1, 2, and 3, as a way of giving readers a feel for the importance of imprisonment for debt in the early Republic.

The immediate lesson learned from these tables is that debtors' prisons were in full use in the early part of the $19^{\text {th }}$ century, and the number of people imprisoned for debt was large both in an absolute and a relative sense. In fact, from the data reported in Table 1 , it can be seen that in many places, the majority of prison populations was composed of debtors. The Prison Discipline Society's estimate is that five out of every six prisoners were in fact in prison for debt in the sampled states, and that this put the total number of people imprisoned for debt, at least across the northeastern United States, well into the tens of thousands.

In spite of the apparent widespread use of the debtors' prison, the data in Table 2 suggest that a relatively large fraction of debts for which people were imprisoned were small. And while sentences for those imprisoned for debt typically were short - less than a month, and frequently only for a couple of days - some of those imprisoned for debt stayed in prison for substantially longer periods of time. (See Table 3) Unfortunately, we don't know whether the length of the sentence for individual prisoners depended on the amount of debt they owed or on other factors. 
In addition to this information, the 1831 report of the Prison Discipline Society tells us that few of those imprisoned for debt actually wound up paying off their debts. According to data from 17 prisons (p. 493 of the 1831 report), out of the 2,057 persons imprisoned for debt, only 294 (14.3\%) actually paid the debt and were discharged, while $1,019(49.5 \%)$ were discharged by the creditor, and $744(36.2 \%)$ were discharged via a poor debtor's oath. The society estimated that the total amount paid out of these debts was $\$ 7,992$, while it put the value of time lost due to imprisonment over the same time period at $\$ 19,987$ (the society used an estimate of $\$ 1$ a day to value time lost). These pieces of information indicate that collectively, those in prison generally wound up not paying their debts, and that the costs of maintaining debtors in prison were substantial. In interpreting these data, however, it is important to remember that if one function of debtor's prison was to prevent default in the first place (as we shall argue in the next section), then the overall gain from imprisonment cannot be reckoned solely in terms of recovered debt.

States began responding to the moral pressures of philanthropic societies such as the Prison Discipline Society, and perhaps the costs incurred in keeping debtors in prison in the third and fourth decades of the $19^{\text {th }}$ century. As previously noted, the initial impetus for abolition of imprisonment for debt was part of the larger societal impetus against cruel punishment. ${ }^{3}$ Indeed, in the decade of the 1840 's, states began enacting legislation that banned imprisonment for debt, except in cases where outright fraud had been committed. Table 4 gives some estimates culled from various sources as to the year

\footnotetext{
${ }^{3}$ The Prison Discipline Society writes "It appears to us impossible, that it can ultimately be maintained under the growing intelligence and liberality of the times, and we confidently trust, that the present generation will not readily yield to their successors the honor of erasing this remnant of barbarism from the civil code of the country.” (Prison Discipline Society, 1831, p 508.)
} 
in which a state ultimately banned imprisonment for debt. ${ }^{4}$ Imprisonment for debt was

banned in the United States for federal court actions in 1841 (Kent, 1848, p. 399).

The notes in Table 4 provide some additional details as to how the law evolved over time in various states. Most of the law pertains to northern and middle states; apparently, in Southern States, there was very little imprisonment for debt, in spite of active laws in many states' constitutions. ${ }^{5}$ We speculate that this might be due to the fact that in the South, many prison boundaries, at least for purposes of debt, were defined to be circumscribed areas around the prisons. ${ }^{6}$ Short of an outright ban of debtors' prisons, the Society noted that states enacted several measures that served to reduce the number imprisoned for debt - measures such as minimum debt amounts for imprisonment, and holding the creditor responsible for jailing fees. In fact, the Prison Discipline Society reported that one prison manager estimated that this latter measure reduced the number imprisoned for debt by roughly one-third (Prison Discipline Society, 1831, p. 493).

\section{An Economic Theory of Debtors' Prisons}

\footnotetext{
${ }^{4}$ This table was constructed through consultation of Coleman (1999), Kent (1848, 1866), Kinne (1842), McMaster (1920), and Prison Discipline Society (1841). There is in fact considerable difficulty in deciphering whether or not, and when, a given state actually banned imprisonment for debt. The confusion arises from multiple dimensions. Some states modified their laws to allow imprisonment for cases in which debtors intended to flee, abscond with, and/or conceal property. This is a different thing than allowing imprisonment only in cases of fraud. Other states - particularly but not only southern states - passed laws that defined the boundary of the debtors' prison to coincide with an area that still allowed prisoners some latitude. These boundaries ranged from a couple of acres near the prison wall, to the entire county or jurisdiction, and in some cases, the entire state; see footnote 6 for more details.

5 This fact was noted by the Prison Discipline Society, who, while noting that "In seventeen prisons heard from in the Northern States, the number of persons imprisoned during the year ending December 30, 1829 was two thousand seven hundred and forty-two," (Prison Discipline Society, 1831, p. 494), added that "In the same number of Prisons in the Southern States, only thirty-five." (Prison Discipline Society, 1831, p. 494)

${ }^{6}$ Coleman (1999) describes this tendency in several Southern States. For example, Coleman (1999, p. 186) notes that in South Carolina in 1841, the boundaries of the prison were defined to be coterminous with the prison's judicial district. In Georgia an act passed in 1820 allowed imprisoned debtors the priveledge of the jail yard, which amounted to an area of 10 acres around the jail. This area was increased to 100 acres in an 1840 act.(Coleman 1999, p. 235).
} 
The economic theory of debtors' prisons to be developed in this section is based on the notion of deterrence (Becker, 1968). In particular, lacking collateral, borrowers could only pledge their freedom as security for the loan. As a result, borrowers faced the choice of either paying back the loan, or going to prison. The argument is identical to that justifying the use of prison for ordinary crimes when offenders either lack sufficient wealth to pay the optimal fine (Polinsky and Shavell, 1984), or seek to shelter their assets from seizure (Levitt, 1997).

To be explicit, consider a borrower who has taken a loan of $L$ dollars and invests in a project that yields an uncertain return. Specifically, suppose that the borrower's return takes a value of $X_{H}$ with probability $p$ and $X_{L}$ with probability $1-p$, where

$$
X_{H}>L>X_{L} \geq 0
$$

Thus, in the low-return state, he is unable to repay the loan. ${ }^{7}$ This need not present a problem if the lender can observe the borrower's realized return. In particular, suppose that the lender required the borrower to pay $L+R$ in the high return state, where $R$ is the interest payment, and $X_{L}$ in the low return state (i.e., he forgives the unpaid balance). One interpretation we offer below is that $X_{L}$ is collateral offered by the borrower as (partial) security for the loan.

Suppose the lender has an opportunity cost of the loan equal to $K$. For example, $K=L(1+r)$, where $r$ is the return on the lender's next best investment (implying that $K>L)$. The lender will therefore expect to just cover his opportunity costs if $p(L+R)+(1-$ p) $X_{L}=K$, or if

\footnotetext{
${ }^{7}$ We assume that the borrower has no other assets besides the return on the investment. Relaxing this assumption would not alter our results provided that the borrower's total assets in the low-return state are insufficient to pay off the loan.
} 


$$
R=\frac{K-(1-p) X_{L}}{p}-L
$$

The borrower will take the loan in the first place if he expects a positive return, or if $p\left[X_{H}\right.$ $-(L+R)] \geq 0 .{ }^{8}$ After substituting for $R$ from (2), this condition becomes

$$
p X_{H}+(1-p) X_{L}-K \geq 0
$$

Thus, the borrower will accept the above "implicit contract" if the expected return from the investment exceeds the opportunity cost of the funds. Under this contract, the borrower agrees to pay a premium in the high return state to compensate for the lender's expected losses in the low return state. We assume hereafter that (3) holds, for otherwise, loans would be unprofitable.

Now suppose that the lender cannot observe the realization of the borrower's return from the project. In this case, the above contract will not work because the borrower will always have an incentive to report low wealth. In other words, the contract is not incentive compatible. The problem is that if lenders expect all borrowers to report low wealth, they will not be able to cover their opportunity costs (given $X_{L}<L<K$ ), and the loan market will fail. ${ }^{9}$

We suggest that debtor prisons were a response to this potential source of market failure. The idea is that the threat of prison makes it costly to default (report low wealth), so it becomes incentive compatible for borrowers to repay the loan in the high wealth state. ${ }^{10}$ The outcome is second-best, however, because prison imposes a deadweight loss on society. Thus, debtor prisons are an efficient response to the above market failure

\footnotetext{
${ }^{8}$ We assume that both the borrower and lender are risk-neutral.

${ }^{9}$ It is possible that lenders would be willing to make smaller loans than $L$, but presumably the borrower's expected return would also fall. And as long as $X_{L}<L$, the problem described here holds.

${ }^{10}$ The explanation is identical to that offered by Levitt (1997) for the seemingly excessive use of prison compared to fines for punishing criminals.
} 
only if the net gain from making funds available to borrowers outweighs the expected social cost of imprisonment.

To examine this function of debtor prisons formally, let $z$ be the length of the prison term imposed on defaulters, $z \geq 0$, let $\alpha$ be the per unit disutility (or opportunity cost) of prison to borrowers (measured in dollars), and let $\beta$ be the per unit cost of prison to society (the cost of incarceration). The total social cost of imprisoning a defaulter for $z$ periods is therefore $(\alpha+\beta) z$.

As before, a borrower who realizes a low return on his investment defaults and pays $X_{L}$ to the lender, but he now must also serve a prison term of $z$ periods. His utility in the low-return state is thus $-\alpha z$. A borrower who realizes a high return, however, now has a choice. He can pay off the loan and receive a return of $X_{H-}(R+L)$, or he can claim a low return and default, which yields a return of $X_{H}-X_{L}-\alpha z$. As argued above, the sole purpose of imprisoning defaulters is to induce truthful revelation by borrowers in the high return state (Levitt, 1997). This requires that the following incentive compatibility (IC) constraint hold

$$
X_{H}-(R+L) \geq X_{H}-X_{L}-\alpha z
$$

or

$$
z \geq \frac{R+L-X_{L}}{\alpha},
$$

where the right-hand side is strictly positive by (1). Rearranging (4) and writing it as an equality yields

$$
R=\alpha z-\left(L-X_{L}\right) .
$$


Equation (5) defines a positively sloped line in $(R, z)$ space with a negative intercept, as shown in Figure 1. Points on or below this line satisfy the IC constraint for high return borrowers.

Now consider lenders. We assume that they must receive a non-negative expected return in order to offer loans. Given IC, this requires

$$
p(R+L)+(1-p)\left(X_{L}-\beta z\right) \geq K
$$

where we assume that lenders (nominally) pay the cost of imprisonment, $\beta z$. (For example, lenders might be taxed to finance the maintenance of debtor prisons. ${ }^{11}$ Writing (6) as an equality and rearranging yields

$$
R=\frac{(1-p) \beta}{p} z+\frac{K-X_{L}}{p}-\left(L-X_{L}\right)
$$

Once again this is a positively sloped line in $(R, z)$ space. Points on or above this participation constraint (PC) guarantee non-negative expected profit for lenders (given IC by high return borrowers).

Note that the intercept of (7) may be positive or negative, but it is clearly higher than the intercept in (5). Further, the slope of (7) is flatter than that in (5) if

$$
\frac{(1-p) \beta}{p}<\alpha,
$$

or if

$$
(1-p) \beta<p \alpha
$$

This condition is important because it is necessary for the IC and PC lines to intersect in the positive quadrant, as shown in Figure $1 .{ }^{12}$ As a result, there exists a region, labeled A

\footnotetext{
${ }^{11}$ Both Massachusetts and Connecticut enacted reforms in the seventeenth century explicitly requiring creditors to pay the jail fees of their imprisoned debtors (Coleman, 1999, p. 251).
} 
in Figure 1, where both the self-selection and non-negative profit conditions simultaneously hold. Note that (8) is more likely to hold the greater is the disutility of prison to borrowers $(\alpha)$, the lower is the cost of prison to society $(\beta)$, and the higher is the probability of a high return on the borrower's investment $(p)$.

If we assume competition among lenders, then the optimal loan "contract," $\left(R^{*}, z^{*}\right)$, maximizes the expected return to borrowers, subject to the IC and PC constraints. The solution can be seen graphically in Figure 1 by plotting the borrower's indifference curves and finding the highest expected return over the shaded region. The expected return for a borrower (given IC) is

$$
E U=p\left(X_{H}-R-L\right)-(1-p) \alpha z
$$

and the corresponding slope of an indifference curve in $(R, z)$ space is given by

$$
\frac{d R}{d z}=\frac{-(1-p) \alpha}{p}<0
$$

Indifference curves are thus negatively sloped straight lines with utility increasing toward the lower left, as shown in Figure 1.

It is clear from the graph that the optimal contract occurs at the intersection point of the two constraints. Thus, solving (5) and (7) simultaneously for $z^{*}$ and $R^{*}$ yields

$$
z^{*}=\frac{K-X_{L}}{p \alpha-(1-p) \beta}
$$

and

$$
R^{*}=\frac{\alpha\left(K-X_{L}\right)}{p \alpha-(1-p) \beta}-\left(L-X_{L}\right) \text {. }
$$

${ }^{12}$ A sufficient condition (along with (8)) is that the intercept of the zero-profit constraint be positive, or not too negative. 
Note that $z^{*}$ is positive given (1) and (8), while $R^{*}$ is positive as long as the intercept of the non-negativity constraint is positive (or not too negative).

It follows from (11) that $\partial z * / \partial p<0$ and $\partial z * / \partial X_{L}<0$. Thus, the equilibrium prison term is decreasing in the probability of a high return on the borrower's investment, and also in the borrower's wealth in the low-return state. Given the above interpretation of $X_{L}$ as collateral, the latter result suggests that better collateral can substitute for prison when borrower wealth is unobservable. It cannot completely solve the incentive compatibility problem, however, unless $X_{L}>K$, in which case there is no risk of default. ${ }^{13}$

Although we have solved for the optimal (second-best) loan contract, there is no guarantee that this contract yields a net social gain. The assumption of competition among lenders awards any surplus to borrowers, so the condition for a net gain is that (9) be non-negative when evaluated at the optimal contract. After substituting (11) and (12) into (9) and rearranging, we find that the condition for $E U^{*}>0$ is

$$
p X_{H}+(1-p) X_{L}-(1-p)(\alpha+\beta) \frac{K-X_{L}}{p \alpha-(1-p) \beta}>0,
$$

or

$$
p X_{H}+(1-p) X_{L}-(1-p)(\alpha+\beta) z^{*}-K>0 .
$$

The loan contract thus yields a net gain if the expected return to the borrower minus the opportunity cost of the lender exceeds the expected deadweight loss (to borrowers and society) from imprisonment in the event of default. Note that this condition may not hold even if condition (3) does given the extra cost of imprisonment under the second-best

\footnotetext{
${ }^{13}$ Collateral serves a different purpose in the current model compared to Bester (1987). Specifically, Bester considers the use of collateral to separate borrowers with unobserved risks of default rather than to provide individual borrower's an incentive to accurately report their return.
} 
contract. In general, (13) is more likely to hold the higher is the expected return from the borrower's investment and the lower is the expected cost of prison.

We saw above that better collateral will reduce the need of lenders to rely on debtors' prison to maintain incentive compatibility, but it will not eliminate it for wealthconstrained borrowers. What will eliminate debtors' prisons is the emergence of easier methods for lenders to acquire information about, or to seize, borrowers' wealth. To illustrate, suppose that borrowers can learn the realization of $X$ with certainty by expenditure of a cost $c$. The lender can then charge $R+L$ in the high return state and $X_{L}$ in the low return state, as in the full information case. The lender's expected profit in this case is

$$
p(L+R)+(1-p) X_{L}-c
$$

Equating this expression to $K$ yields the equilibrium interest payment

$$
R=\frac{c+K-(1-p) X_{L}}{p}-L,
$$

which differs from the full information value in (2) by the addition of $c / p$. In equilibrium, the expected return to the borrower is

$$
E U^{*}=p X_{H}+(1-p) X_{L}-K-c
$$

which is less than the expected return under certainty by the cost of information, $c$.

Finally, comparing (16) to (13) shows that lenders will adopt the current technology in favor of prison when

$$
c<(1-p)(\alpha+\beta) z^{*}
$$

The abolition of debtors' prisons therefore becomes more likely as the cost of information acquisition decreases and/or as prison costs rise. This prediction forms the basis for the empirical analysis in the next section. 


\section{Empirical Analysis}

This section undertakes an empirical analysis of debtors' prisons, focusing on those factors that led to their eventual demise. As Table 4 revealed, many states took actions to restrict or ban imprisonment for debt in the early decades of the $19^{\text {th }}$ century. Some states banned the practice outright, while others adopted a more gradual approach. In many states, for example, imprisoning women for debt was first banned, while in others a lower bound on debts for which one could be imprisoned was put in place. ${ }^{14} \mathrm{~A}$ useful reference in tracking the ultimate progress of laws over time is James Kent's Commentaries on American Law, which was first published in 1826 and went through twelve editions running through 1901. (In the process, it picked up additional authors, including such notable legal scholars as Oliver Wendell Holmes, Jr. and John M. Gould.) Although it did not give explicit dates as to when imprisonment for debt in every state was banned, the Commentaries do list, as of 1848 (and perhaps a little bit earlier allowing for research and publication lags), the states that still allowed imprisonment for debt in some form, and those that had banned it. The 1866 list in the Commentaries reproduces the same text.

Kent's typology of states allows us to investigate the characteristics of those states that banned imprisonment for debt in the 1840's - we will call these "early ban states" with states that did not ban imprisonment for debt until much later. Obviously, an econometric analysis of the debt-banning decision cannot be too detailed, and the evidence presented here will necessarily be more suggestive than definitive.

\footnotetext{
${ }^{14}$ Another practice adopted in many states was to exempt Revolutionary war veterans from imprisonment for debt.
} 
To identify independent variables that might be used to explain the incidence of early versus late banning of imprisonment for debt, we shall rely primarily on state-level data from the 1840 census. One the one hand, this greatly limits the set of available independent variables that we might use, as there is in the end very little data in the 1840 census. On the other hand, the 1840 census represents a considerable improvement in both quality and quantity of data over earlier U.S. censuses. The nature of the available data and their relationship to the hypotheses described earlier in the paper are presented in Table 5.

The variables in the table can essentially be broken into categories - those that we think proxy for the importance of commercial interests, and those that may function as proxies for the costs of being informed and maintaining information about borrowers. Thus, we may view variables that have something to do with the dissemination of information as variables that measure the state's ability to come up with an alternative to the debtors' prison, which should rely on the state's capacity to maintain and develop information about potential borrowers. None of the variables is perfect. As we shall see, one of the variables that functions as a pretty good predictor of whether or not a state banned the use of debtors' prisons earlier rather than later is the state of the publishing industry, whether measured by the number of publications - daily, weekly, or semiweekly newspapers and periodicals per capita - or by statewide investment in the printing industry. While this may in fact be a good proxy for the presence of the ability to maintain stores of information about potential borrowers, it might just as well be measuring the ability of anti-imprisonment propogandists to reach and convince the population of their case. Unfortunately, we cannot distinguish which of these two is 
really at work. With a little imagination, one can see that this is a problem with virtually all of our proxies.

Given that caveat, Table 6 presents some summary statistics for the indicated variables, both in aggregate, and broken down by whether or not the state banned imprisonment for debt earlier or later, according to Kent's criterion. One can begin to get a feel from Table 6 which of the variables described in Table 5 appear to vary systematically between states that were deemed by Kent to enact relatively earlier bans on imprisonment for debt. Two things stand out from the table. First, it appears that states with better-developed and more important publishing industries were quicker to abolish imprisonment for debt. This is evidenced by the fact that states that banned imprisonment for debt earlier apparently tend to have relatively larger newspaper, publishing, binding, and printing sectors, regardless as to how one measures these variables.

Table 6 further reveals a tendency for states with relatively more professionals and engineers, and smaller illiterate populations, to favor earlier bans on imprisonment for debt. This could likely be the case for two reasons. Most plainly, more educated populations are more likely to be up on current events and debates, and debates over imprisonment for debt were common in the early part of the $19^{\text {th }}$ century. An additional tendency is for the relative numbers of people employed in commerce to correlate positively with early banning of imprisonment for debt. This is likely because the development of commerce is strongly correlated with the overall development of the economy and of more effective means both for screening debtors' ability to repay and for ensuring timely repayment. 
Table 7 presents some results of logistic regressions in which the dependent variable is whether or not the state banned imprisonment for debt in our around the year 1840 , or whether it banned imprisonment much later, once again according to the criterion of Kent. These results largely bear out what we learned from inspection of Table 6. The first thing to notice from Table 7 is that all the regressions include the per capita investment in publishing, printing, and binding. This is because a little experimentation reveals that, of the several proxies we described in Tables 5 and 6 to capture the state of the publishing industry, this one consistently outperformed the others. Moreover, in a situation in which degrees of freedom is an issue, parsimony is important.

The logistic regression results continue to include other kinds of proxies in light of this, and the lesson is that most of them - even those that Table 6 suggest might help in predicting the incidence of early imprisonment bans - do not bring much to the empirical model that is not already captured by the per capita investment in the publishing industry. In every model we estimated, this variable was strongly positive and significant, indicating that those states with a more active and developed publishing industry were more likely to enact early bans on imprisonment for debt. As suggested, this result makes perfect sense in light of our hypothesis.

\section{Conclusion}

The idea of debtors' prisons, on its face, seems irrational. How, one asks, can a borrower be expected to pay back a loan when imprisoned? Yet debtors' prisons have flourished throughout history and were even imported into the United States, where they endured until the middle of the nineteenth century. This suggests that they must have 
served some useful function in the operation of early credit markets. The analysis in this paper has sought to explain the economic reasons for their existence, and ultimately, for their demise.

While the imprisonment of debtors no doubt elicited some amount of repayment of delinquent loans by benefactors of the debtor, we argued that its primary function was to deter default in the first place by giving borrowers an incentive to disclose hidden assets that could be used for repayment. Imprisonment was costly, however, and was therefore destined to be replaced by a more efficient means of preventing borrowers from sheltering assets. Empirical analysis of state laws banning imprisonment of debtors in the United States provides support for this argument. In particular, the results suggest that those states in which the publishing industry developed sooner, thus facilitating the flow of information, were more likely to enact early bans of imprisonment for debt. 


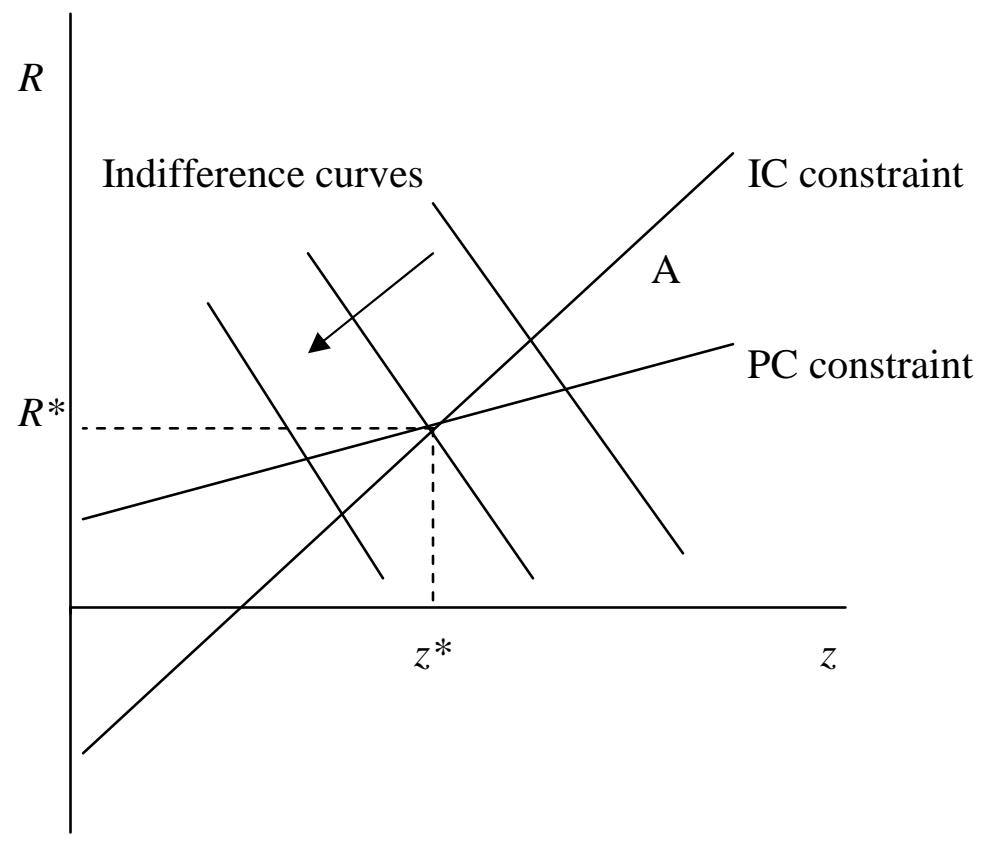

Figure 1: Optimal loan contract with self-selection. 
Table 1 - Imprisonment for Debt in 1829

\begin{tabular}{|c|c|c|c|}
\hline Cities, Towns, and States & Prisoners & $\begin{array}{c}\text { Statewide } \\
\text { totals }\end{array}$ & $\begin{array}{c}\text { Ratio, debtors } \\
\text { to other } \\
\text { prisoners }\end{array}$ \\
\hline $\begin{array}{l}\text { Concord, N.H. } \\
\text { Taunton, Mass. } \\
\text { Worcester, Mass. } \\
\text { Boston, Mass. } \\
\text { Massachusetts } \\
\text { East Greenwich, R.I. } \\
\text { Newport, R.I. } \\
\text { Rhode Island } \\
\text { Pennyan, N.Y. } \\
\text { Courtland Village, N.Y. } \\
\text { Buffalo, N.Y. } \\
\text { New York City, N.Y. } \\
\text { New York } \\
\text { Belvidere, N. J. } \\
\text { Flemington, N. J. } \\
\text { Philadelphia, Penn. } \\
\text { Pennsylvania } \\
\text { Baltimore, M.D. } \\
\text { Maryland }\end{array}$ & $\begin{array}{c}31 \\
126 \\
271 \\
1211 \\
\\
80 \\
78 \\
\\
103 \\
112 \\
338 \\
3000\end{array}$ & 3000 & $\begin{array}{l}4 \text { to } 1 \\
5 \text { to } 1 \\
8 \text { to } 1\end{array}$ \\
\hline $\begin{array}{l}\text { Northern and Middle States } \\
\text { Combined }\end{array}$ & & & $\sim 5$ to 1 \\
\hline
\end{tabular}

Notes: Philadelphia numbers are for the 8 months ending February 25, 1830. Information compiled from the $5^{\text {th }}$ report of the Prison Discipline Society, as published in the North American Review Vol. 32., Gray and Bowen, Boston: 1831. 
Table 2 - Magnitude of Debt, for a sample of prisons and the city of Boston, 1829.

\begin{tabular}{l|ccccc}
\hline \multirow{2}{*}{ Debt size } & \multicolumn{3}{|c}{ All prisons } & \multicolumn{3}{c}{ Boston } \\
& $\begin{array}{c}\text { Prisons } \\
\text { reporting }\end{array}$ & $\begin{array}{c}\text { Total } \\
\text { imprisoned }\end{array}$ & Percent & $\begin{array}{c}\text { Total } \\
\text { imprisoned }\end{array}$ & Percent \\
\hline Less than $\$ 1$ & 12 & 62 & $1 \%$ & 30 & $3 \%$ \\
$\$ 1$ to $\$ 5$ & 30 & 595 & $14 \%$ & 233 & $29 \%$ \\
$\$ 5$ to $\$ 20$ & 32 & 2184 & $53 \%$ & 314 & $38 \%$ \\
\$20 to \$100 & 32 & 902 & $22 \%$ & 142 & $17 \%$ \\
More than $\$ 100$ & 53 & 416 & $10 \%$ & 98 & $12 \%$ \\
\hline Total & & 4159 & $100 \%$ & 817 & $100 \%$ \\
\hline
\end{tabular}

Notes: Boston Data pertains to June 6, 1829 to February 24, 1830. Information compiled from the $5^{\text {th }}$ report of the Prison Discipline Society, as published in the North American Review Vol. 32., Gray and Bowen, Boston: 1831. 
Table 3 - Sentence length for debtors, 1829.

\begin{tabular}{l|cc} 
Sentence Length & Number (15 prisons) & Percent \\
\hline Less than 1 Day & 269 & $18 \%$ \\
1 to 5 Days & 323 & $22 \%$ \\
5 to 10 Days & 203 & $14 \%$ \\
10 to 20 Days & 154 & $11 \%$ \\
20 to 30 Days & 83 & $6 \%$ \\
More than 30 Days & 431 & $29 \%$ \\
\hline Total & 1463 & $100 \%$ \\
\hline
\end{tabular}

Notes: Information compiled from the $5^{\text {th }}$ report of the Prison Discipline Society, as published in the North American Review Vol. 32., Gray and Bowen, Boston: 1831. 
Table 4 - Evolution of state laws, imprisonment for debt.

\begin{tabular}{|c|c|c|}
\hline State & Year & Notes: \\
\hline Alabama & 1839 & \\
\hline Arkansas ${ }^{*}$ & 1843 & \\
\hline Connecticut & 1842 & $\begin{array}{l}1826 \text { - women excluded } \\
1837 \text { - no petty debts }\end{array}$ \\
\hline Delaware & 1841 & 1841 - only debts $>50 \$ ?$ \\
\hline Florida & $<1850$ & 1824 - women excluded \\
\hline Georgia* & 1858 & 1847 - women excluded \\
\hline Illinois ${ }^{*}$ & & \\
\hline $\begin{array}{l}\text { Indiana* } \\
\text { Iowa (Terr.) }\end{array}$ & $1842 ?$ & 1838 - Prison bounds coextensive with the county \\
\hline Kentucky ${ }^{*}$ & $1821 ?$ & 1820 - women excluded \\
\hline Louisiana & 1840 & \\
\hline Maine* & & $1822-$ only debts $>5 \$$ \\
\hline Maryland ${ }^{*}$ & 1851 & 1824 - women excluded \\
\hline Massachusetts & 1857 & $\begin{array}{l}1811-\text { only debts }>5 \$ \\
1831-\text { only debts }>10 \$ \\
\text { women excluded }\end{array}$ \\
\hline Michigan & 1839 & \\
\hline Mississippi & 1839 & \\
\hline Missouri* & 1843 & \\
\hline New Hampshire & 1840 & $\begin{array}{l}1818 \text { - only debts }>\$ 13.33 \\
1831 \text { - women excluded }\end{array}$ \\
\hline New Jersey & 1842 & 1818 - women excluded \\
\hline New York & 1831 & $\begin{array}{l}1819-\text { only debts }>10 \$ \\
1828 \text { - women excluded }\end{array}$ \\
\hline North Carolina* & $>1850$ & $\begin{array}{l}1823 \text { - women excluded } \\
1844 \text { - proof of concealment or transfer }\end{array}$ \\
\hline Ohio & 1838 & \\
\hline Pennsylvania & 1842 & $\begin{array}{l}1819 \text { - women excluded, } \\
1833 \text { - no petty debts }\end{array}$ \\
\hline Rhode Island $^{*}$ & $>1900$ & \\
\hline South Carolina* & $>1850$ & $\begin{array}{l}1825 \text { - only debts }>20 \$ \\
1841 \text { - judicial district boundaries }\end{array}$ \\
\hline Tennessee & 1840 & \\
\hline Vermont & 1838 & $\begin{array}{l}1819 \text { - only debts }>15 \$ \\
1834 \text { - women excluded }\end{array}$ \\
\hline Virginia $^{*}$ & 1873 & 1849 - "partial abolition" \\
\hline Wisconsin (Terr.) & 1842 & \\
\hline
\end{tabular}

Notes: * marks states which Kent (1848. 1866) asserts still allowed some form of imprisonment for debt as of the writing of his book. The table was constructed through consultation of Coleman (1999), Kent (1848, 1866), Kinne (1842), McMaster (1920), and Prison Discipline Society (1841). . 
Table 5 - 1840 census data and model hypotheses

\begin{tabular}{|c|c|c|}
\hline Variable & Relationship to model & $\begin{array}{l}\text { Hypothesized } \\
\text { impact }\end{array}$ \\
\hline Year of statehood & $\begin{array}{l}\text { Year of statehood may influence } \\
\text { the state of development of capital } \\
\text { markets or inertia in previous state } \\
\text { laws }\end{array}$ & Ambiguous \\
\hline Population density & $\begin{array}{l}\text { Proxy for the development of } \\
\text { capital markets }\end{array}$ & Earlier ban \\
\hline Fraction population urban & $\begin{array}{l}\text { Proxy for the development of } \\
\text { capital markets }\end{array}$ & Earlier ban \\
\hline Southern state dummy & $\begin{array}{l}\text { Difference in prison sentencing and } \\
\text { the efficacy of debtors prison }\end{array}$ & Ambiguous \\
\hline $\begin{array}{l}\begin{array}{l}\text { Fraction voting } \\
\text { presidential election }\end{array}\end{array}$ & $\begin{array}{l}\text { Population preference for interests } \\
\text { of commerce }\end{array}$ & Later ban \\
\hline $\begin{array}{l}\text { Number of newspapers and } \\
\text { periodicals per } 10000 \text { pop. }\end{array}$ & $\begin{array}{l}\text { Better flow of information about } \\
\text { borrowers, more anti-imprisonment } \\
\text { propaganda }\end{array}$ & Earlier ban \\
\hline $\begin{array}{l}\text { Employment in publishing, } \\
\text { newspapers, and binding per } 1000 \\
\text { pop. }\end{array}$ & $\begin{array}{l}\text { Same as above, but measure may } \\
\text { better control for scale }\end{array}$ & Earlier ban \\
\hline $\begin{array}{l}\text { Dollars invested in printing, } \\
\text { newspapers and periodicals per cap. }\end{array}$ & $\begin{array}{l}\text { Same as above, but measure may } \\
\text { better control for scale }\end{array}$ & Earlier ban \\
\hline Emp. in navigation per 1000 pop. & $\begin{array}{l}\text { Proxy for the ease of flight from } \\
\text { creditors or importance of } \\
\text { commerce }\end{array}$ & Later ban \\
\hline $\begin{array}{l}\text { Grocery and dry goods stores per } \\
\text { capita }\end{array}$ & $\begin{array}{l}\text { Proxy for the importance of } \\
\text { commercial interests }\end{array}$ & Later ban \\
\hline $\begin{array}{l}\text { Commercial foreign trade and } \\
\text { commission houses per } 1000 \text { pop. }\end{array}$ & $\begin{array}{l}\text { Proxy for the importance of } \\
\text { commercial interests }\end{array}$ & Later ban \\
\hline $\begin{array}{l}\text { Capital invested in grocery and dry } \\
\text { goods stores, } \$ \text { per cap. }\end{array}$ & $\begin{array}{l}\text { Same as above, but measure may } \\
\text { better control for scale }\end{array}$ & Later ban \\
\hline $\begin{array}{l}\text { Capital invested in commercial } \\
\text { houses, } \$ \text { per cap. }\end{array}$ & $\begin{array}{l}\text { Proxy for the importance of } \\
\text { commercial interests }\end{array}$ & Later ban \\
\hline
\end{tabular}


Table 6 - Summary Statistics

\begin{tabular}{|c|c|c|c|}
\hline Variable & $\begin{array}{c}\text { Early } \\
\text { adoption } \\
(n=17)\end{array}$ & $\begin{array}{c}\text { Late } \\
\text { adoption } \\
(n=12)\end{array}$ & $\begin{array}{c}\text { Full sample } \\
\quad(n=29)\end{array}$ \\
\hline Year of statehood & $\begin{array}{c}1807.41 \\
(23.57)\end{array}$ & $\begin{array}{c}1802.75 \\
(17.87)\end{array}$ & $\begin{array}{c}1805.48 \\
(21.17)\end{array}$ \\
\hline Population density & $\begin{array}{c}28.72 \\
(25.89)\end{array}$ & $\begin{array}{c}23.89 \\
(27.06)\end{array}$ & $\begin{array}{c}26.72 \\
(26.01)\end{array}$ \\
\hline Fraction population urban & $\begin{array}{c}9.55 \\
(11.17)\end{array}$ & $\begin{array}{r}12.80 \\
(8.73)\end{array}$ & $\begin{array}{c}9.21 \\
(11.66)\end{array}$ \\
\hline Southern state dummy variable & $\begin{array}{c}0.29 \\
(0.47)\end{array}$ & $\begin{array}{c}0.42 \\
(0.51)\end{array}$ & $\begin{array}{c}0.34 \\
(0.48)\end{array}$ \\
\hline Percent voting Whig $(n=25)$ & $\begin{array}{l}53.44 \\
(4.85)\end{array}$ & $\begin{array}{l}52.69 \\
(6.61)\end{array}$ & $\begin{array}{l}53.11 \\
(5.58)\end{array}$ \\
\hline Newspapers and periodicals per 10000 pop. & $\begin{array}{l}1.17^{* * *} \\
(0.38)\end{array}$ & $\begin{array}{l}0.83 \\
(0.38)\end{array}$ & $\begin{array}{l}1.03 \\
(0.41)\end{array}$ \\
\hline Engineers, professionals per 1000 pop. & $\begin{array}{l}4.64^{* * * * *} \\
(0.44)\end{array}$ & $\begin{array}{l}3.17^{* * * * *} \\
(0.25)\end{array}$ & $\begin{array}{l}4.03 \\
(1.64)\end{array}$ \\
\hline Illiterate whites 25 or older, per 100 pop. & $\begin{array}{l}3.27^{* *} \\
(2.78)\end{array}$ & $\begin{array}{l}6.14^{* * *} \\
(3.06)\end{array}$ & $\begin{array}{l}4.46 \\
(3.19)\end{array}$ \\
\hline Employment in publishing per 1000 pop. & $\begin{array}{l}0.71^{* * *} \\
(0.37)\end{array}$ & $\begin{array}{l}0.41^{* * *} \\
(0.28)\end{array}$ & $\begin{array}{c}0.59 \\
(0.36)\end{array}$ \\
\hline Per capita investment in printing industries & $\begin{array}{c}0.39^{* * * *} \\
(0.21)\end{array}$ & $\begin{array}{c}0.18^{* * * * *} \\
(0.09)\end{array}$ & $\begin{array}{c}0.30 \\
(0.20)\end{array}$ \\
\hline Employment in navigation per 1000 pop. & $\begin{array}{c}6.27 \\
(8.68)\end{array}$ & $\begin{array}{c}4.86 \\
(7.07)\end{array}$ & $\begin{array}{c}5.69 \\
(7.95)\end{array}$ \\
\hline Groceries, dry goods stores per 10000 pop. & $\begin{array}{c}38.24 \\
(15.27)\end{array}$ & $\begin{array}{c}33.19 \\
(19.71)\end{array}$ & $\begin{array}{c}36.15 \\
(17.10)\end{array}$ \\
\hline Per capita investment groceries, dry goods & $\begin{array}{l}15.92 \\
(7.99)\end{array}$ & $\begin{array}{l}13.63 \\
(5.93)\end{array}$ & $\begin{array}{l}14.97 \\
(7.19)\end{array}$ \\
\hline Trade and commission houses per 1000 pop. & $\begin{array}{c}2.88 \\
(3.14)\end{array}$ & $\begin{array}{c}2.04 \\
(2.46)\end{array}$ & $\begin{array}{c}2.54 \\
(2.87)\end{array}$ \\
\hline Employed in commerce, per 1000 pop. & $\begin{array}{c}8.12^{*} \\
(5.40)\end{array}$ & $\begin{array}{l}5.19^{*} \\
(0.79)\end{array}$ & $\begin{array}{c}6.91 \\
(4.66)\end{array}$ \\
\hline Per capita investment, trade and commission & $\begin{array}{c}8.23 \\
(12.23)\end{array}$ & $\begin{array}{c}4.14 \\
(5.31)\end{array}$ & $\begin{array}{c}6.54 \\
(10.04)\end{array}$ \\
\hline Employment in navigation per 1000 pop. & $\begin{array}{c}6.27 \\
(8.68)\end{array}$ & $\begin{array}{c}4.86 \\
(7.07)\end{array}$ & $\begin{array}{c}5.69 \\
(7.95)\end{array}$ \\
\hline
\end{tabular}

Notes: Asterisks denote significance levels in two-sample T-tests. $*=.10$ significance level, $* *=.05$ significance level, $* * *=0.01$ significance level. Significant differences appear in bold type. All T-tests were performed assuming unequal variances. 
Table 7 - Logistic regression results: Dependent variable = early abolishment of imprisonment for debt

\begin{tabular}{|c|c|c|c|c|c|c|}
\hline & $\mathrm{A}$ & $\mathrm{B}$ & $\mathrm{C}$ & $\mathrm{D}$ & $\mathrm{E}$ & $\mathrm{F}$ \\
\hline Per cap. investment, publishing & $14.186^{* * *}$ & $23.766 * *$ & $8.657 * *$ & $12.768 * *$ & $21.541 * * *$ & $12.721 * * *$ \\
\hline & -2.792 & -2.462 & -2.554 & -2.433 & -2.977 & -2.872 \\
\hline Population density & $\begin{array}{c}-0.031 \\
(-1.458)\end{array}$ & & & & & \\
\hline Fraction population urban & & $\begin{array}{l}-0.199 * \\
(-1.669)\end{array}$ & & & & \\
\hline Engineers, professionals & & & $\begin{array}{l}0.493^{*} \\
-1.851\end{array}$ & & & \\
\hline Southern state dummy & & & & $\begin{array}{c}0.451 \\
-0.392\end{array}$ & & \\
\hline Year of statehood & & & & $\begin{array}{c}0.035 \\
-1.232\end{array}$ & & \\
\hline Per cap. investment, groceries & & & & & $\begin{array}{c}-0.233 * * \\
(-2.407)\end{array}$ & \\
\hline Employed in navigation & & & & & & $\begin{array}{c}0 \\
(-1.015)\end{array}$ \\
\hline Per cap. investment, trade & & & & & & $\begin{array}{c}-0.05 \\
(-0.862)\end{array}$ \\
\hline Constant & $\begin{array}{c}-2.353 * * \\
(-2.187)\end{array}$ & $\begin{array}{c}-3.642 * * \\
(-2.292)\end{array}$ & $\begin{array}{c}-3.749 * * \\
(-2.431)\end{array}$ & $\begin{array}{l}-66.967 \\
(-1.265)\end{array}$ & $\begin{array}{c}-1.414 \\
(-1.388)\end{array}$ & $\begin{array}{c}-2.467 * * \\
(-2.498)\end{array}$ \\
\hline Pseudo-R2 & 0.331 & 0.441 & 0.341 & 0.335 & 0.381 & 0.302 \\
\hline $\mathrm{N}$ & 29 & 29 & 29 & 29 & 29 & 29 \\
\hline
\end{tabular}




\section{References}

Becker, Gary. 1968. "Crime and Punishment: An Economic Approach," Journal of Political Economy 76: 169-217.

Bester, H.1987. "The Role of Collateral in Credit Markets with Imperfect Information," European Economic Review 31: 887-899.

Coleman, Peter. 1999. Debtors and Creditors in America: Insolvency, Imprisonment for Debt, and Bankruptcy, 1607-1900. Washington, DC: Beard Books.

Dickens, Charles. 2006 [1850]. David Copperfield. New York: Bantam.

Ford, Richard. 1926. “Imprisonment for Debt,” Michigan Law Review 25 (1): 24-49.

Holton, W. 2007. Unruly Americans and the Origins of the Constitution. New York: Hill and Wang.

Kent, James. 1848. Commentaries on American Law, Vol. 2, $6^{\text {th }}$ Ed. New York: William Kent.

Kent, James. 1866. Commentaries on American Law, Vol. 2, $11^{\text {th }}$ Ed. James Comstock, editor. Boston: Little, Brown and Co.

Kinne, Asa. 1842. The Laws of the Different States and Territories of the United States on Imprisonment for Debt. New York: W. E. Dean.

Levitt, Steven. 1997. "Incentive Compatibility Constraints as an Explanation for the Use of Prison Sentences instead of Fines," International Review of Law and Economics 17: 179-192.

Mann, Bruce. 2002. Republic of Debtors: Bankruptcy in the Age of American Independence. Cambridge, MA: Harvard Univ. Press.

McMaster, John Bach. 1920. A History of the People of the United States, From the Revolution to the Civil War, Vol. 8., 1841-1850. New York and London: D. Appleton and Co.

Polinsky, A. Mitchell, and Steven Shavell. 1984. "The Optimal Use of Fines and Imprisonment," Journal of Public Economics 24: 89-99.

Prison Discipline Society, 1831. "Imprisonment for Debt: Fifth Annual Report of the Board of Managers of the Prison Discipline Society," North American Review 32: 490508. 
Prison Disciplne Society, 1841. $16^{\text {th }}$ Annual Report of the Prison Discipline Society. Boston: Prison Discipline Society. 